\title{
CULTURAL SIMILARITY EFFECT ON THE RELATIONSHIP QUALITY BETWEEN EXPORTERS AND INTERMEDIARIES AND EXPORT PERFORMANCE OF SMES
}

\author{
Norliza Hamir Basah* \\ Universiti Utara Malaysia \\ Siew-Imm Ng \\ Universiti Putra Malaysia \\ Jo-Ann Ho \\ Universiti Putra Malaysia \\ Raja Nerina Raja Yusof \\ Universiti Putra Malaysia
}

\begin{abstract}
Quality is a crucial component for developing a relationship between SME exporters and exporter intermediaries. The key role that quality plays in enhancing the performance of SMEs in foreign markets has been highlighted. Additionally, in order to support the development of such a relationship, cultural similarity is a fundamental catalyst particularly for initial stages of the internationalization process due to the belief that companies perform better in foreign markets if they possess similar cultural backgrounds. However, there have been previous studies have reported inconsistencies in findings between cultural similarity and performance. Hence, the purpose of this study is to examine what are the mechanisms in which cultural similarity can lead to relationship quality as well as performance. This current study used the Internationalization Process (IP) Theory and the Relational Exchange Theory (RET) to examine the synergistic effect of several factors on export performance within the context of Malaysian exporting SMEs and exporter intermediaries. A quantitative method was employed in this study where the primary data derived from 203 SME manufacturing exporting firms in Malaysia. Structural Equation Modeling using SmartPLS was used for data analysis. The result indicates that all hypotheses are supported. Findings may contribute to enriching the existing literature on export performance of Malaysian SMEs which use foreign intermediaries.
\end{abstract}

Keywords: SME; Export performance; Intermediaries; Relationship quality; Cultural similarity

Received: 4 June 2018

Accepted: 30 December 2019

\footnotetext{
* Corresponding Author: Norliza Hamir Basah, School of International Studies, Universiti Utara Malaysia, 06010 UUM, Kedah, Malaysia. Email: hnorliza@uum.edu,my
} 


\section{INTRODUCTION}

Rapid economic growth and advances in technology have led to SMEs being faced with a number of export barriers when they expand their businesses to foreign markets (Pinho, 2013). It is a commonly accepted fact that SMEs are lacking in finance, foreign market intelligence, knowledge, skills, reputation and international contacts (Kumar \& Singh, 2017; Agndal, Chetty, \& Wilson, 2008). Consequently, SMEs normally use the services of experts such as exporter intermediaries to overcome the complexities inherent in the export market and to reduce such inadequacies (Root, 1994). According to Balabanis (2000), intermediaries can help exporters in conducting market research, identifying foreign buyers, completing the necessary documentations and managing all related matters for foreign operations. In addition, foreign intermediaries have the capability to help exporters to close the knowledge gap and reduce risks and uncertainties when doing business in an unfamiliar foreign market. When exporting firms hire intermediary services, they hope that they can perform well in international arena. For example, when SMEs decide to use intermediaries, the intermediaries should possess specific knowledge regarding their countries which will save the exporting company costs, such as marketing research and negotiating costs (Pinho, 2016). As such, choosing reliable foreign intermediaries is of great importance to help exporters to manage their foreign operations.

However, earlier studies have reported that using intermediary services sometimes can create several major issues. First, the cultural issue has been acknowledged as a fundamental pitfall (Meirovich, 2012) in developing high quality relationships between exporters and intermediaries. For instance, cultural differences can negatively influence efficiency and export performance. Second, using intermediary services can increase conflict between exporters and intermediaries since exporters tend to lose their control of foreign operations, such as marketing strategy, selection of customers and managing other related resources (Kulhmeier \& David, 2010). Third, transactional costs will also increase when exporters using intermediary services (Obadia, 2010; Pinho, 2016; Erdil, 2014).

Thus, due to these circumstances, the concepts of trust, commitment and cooperation should be key elements for developing a high quality relationship between SME exporters and their intermediaries (Obadia, 2010). This could be due to the strong relationship between SME exporters and their intermediaries is crucial for managing the complex nature of exporting and eventually succeeding in managing and developing their business operations (Kuhlmeier \& David, 2010). The high quality relationship between exporters and intermediaries perhaps can enhance exploitation of specific business prospects in foreign markets to improve export performance (Pinho, 2013). Accordingly, Musteen, Francis, and Data (2010) supported that relational factors such as trust, commitment and cooperation have significant impacts on internationalization performance. However, to date, very few studies have discussed the factors that can possibly influence the relationship quality between exporters and intermediaries (Erdil, 2014; Pinho, 2016); and what has been reported is mostly based on evidence from developed nations (Saleh, Ali, \& Mavondo, 2014). Nevertheless, the socio-economy, the variation of income, infrastructure, level of technological advancement and prevalence resources endowment are factors that differentiate the developed and developing country's markets and such differentiations can severely affect international exchange opportunities and exchange partners' behavior (Frazier, Gill, \& Kale, 1989). Cultural issues inherent in network relationship that vary between developed and developing countries should be further examined (Saleh et al., 2014). Moreover, cultural issues are regarded as one of the major 
contributor in cross border relationship failure (Meirovich, 2012). Due to this reason, there is a general consensus in the literature that a cultural fit between partners should exist in order for their collaboration to succeed. However, neither the nature of this fit nor the direction of cultural influence has been fully understood, due to the inconclusive results of empirical research (Meirovich, 2012). Essentially, this study explores to what extent cultural similarity can impetus trust and lead to commitment and cooperation which finally manifested the export performance; especially in relation to how those factors are inter-related in explaining export performance.

\subsection{Overview of Malaysia's Export Performance}

Malaysia SMEs have not contributed much to exports despite the Malaysian government being highly supportive of internationalization by SMEs to improve exporting activities and national trade performance (Ahmadian, 2012). Export performance is an indicator of a country's economic growth and is also important for a firm's competitiveness (Zou, Taylor, \& Osland, 1998). Malaysia's export performance is greatly influenced by SMEs since they contribute $17.8 \%$ of total exports (MATRADE, 2018). Malaysia has recognized SMEs as the backbone of its economy as this sector plays a significant role in the nation's economic growth. SMEs also account close to $99 \%$ of the total business establishments in the country (MATRADE, 2018). Specifically, as shown in Figure 1, that this sector contributes 36.6\% to the nation's Gross Domestic Product (GDP), and $65 \%$ to employment opportunities (Department of Statistics Malaysia, 2017). However, this 36.6\% contribution to GDP is lower than that of other middle income nations (39\%) and high income nations (51\%) [Department of Statistics Malaysia, 2015 \& SME Corporation, 2015]. As noted by Datuk Seri Mustapha Muhammad, Minister of International Trade and Industry that time, SMEs in Malaysia have broadened their export-base but the level of participation in export activities remains low (MATRADE, 2014).

Figure 1: Contribution of SMEs to the Malaysian Economy

Source: MATRADE, 2018

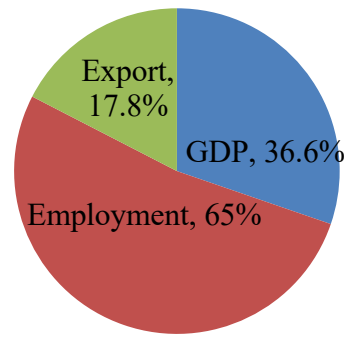




\section{LITERATURE REVIEW ON ISSUES OF EXPORT PERFORMANCE}

In general, export performance could be defined as a firm's level of achievement related to export activities in foreign market (Shoham, 1996). No established definition exists regarding performance in export literature (Navarro, Losada, Ruzo, \& Diez, 2010). This is because performance can be assessed differently by individual firms according to a tremendous success for one company may be considered a failure for another. SMEs have an affinity for exports; however, no matter which mode of internalization is adopted, the elements of culture and relationship do pose problems (Pinho, 2013). One form of relationship that could accelerate the internationalization process, provide access to new knowledge and seek new market opportunities is the network relationship (Jeong, 2017). However, majority of past literature had focused on strategies pertaining to product, promotion and distribution instead of the quality of the relationship with foreign intermediaries regarding export performance (Erdil, 2014). According to Hunt (2000), a relationship comprises intangible assets that can contribute to company performance. By its nature, relational assets such as trust, commitment and cooperation are critical to build for maintain superior export performance. This statement is consistent with the RET theory, which states that developing trust can lead to commitment and cooperation crucial components in seeking better performance by creating foreign business relationship. The RET also points out that trusted exchanges lead to positive outputs.

RET posits that trust between partners is the impetus for the belief that they are engaged in behavior which is honest, fair and sincere. Commitment implies a long-term orientation characterized by the fulfillment of the requirements of the relationship, whilst, cooperation is crucial for the joint effort and collaborative actions of partners (Leonidou et al., 2013). Along this line of reasoning, Erdil (2014) asserted that, to yield better outcomes to promote efficiency and effectiveness, both trust and commitment are compulsory in cross border-relationships. In the relationship management, trust is important to determine either the partner is a viable business partner (Nevin $\&$ Money, 2008). Whilst, inter-organizational commitment emerges as the most important factors that can influence export performance (Erdil, 2014). In addition, cooperation is a strategic factor that can orientate business partner to resolve the problem together with regard to foreign operations (Cavusgil \& Zou, 1994). Nevertheless, to date, there are very few studies that investigate the crucial elements of the relationship quality which consist of trust, commitment and cooperation (Bloemer et al., 2013; Erdil, 2014) that link the exporter and intermediaries' relationship. Erdil (2014) claimed that the reason to consider relational perspective is because exporting does not involve economic or business transactions, it is also heavily dependent on the relationship quality between parties. This argument is consistent with Morgan et al. (2006) which confirmed that a firm's relational elements are crucial for the success of export operations (Hador, 2017).

Despite the importance of the relational transaction that influences firm performance, the fundamental aspects that lead to relational elements are unclear. Literature on exports has established a view that culture plays a pivotal role in foreign business relationship (Prime, Obadia \& Vida, 2009). In international business, culture issues are critical as they can impact on partnering relationships in the international exchange process (Saleh et al., 2014). Exporter and marketers are frequently challenged by new and unfamiliar cultures. The perceived dissimilarity between the home country and the target country is termed as psychic distance or cultural distance (Klein \& Roath, 1990). According to Boyacigiler (1990) the difference of culture in business relationship often aggravates the challenge of acquisition and interpretation of foreign market intelligence, thus 
negatively impacting export performance. There is a general consensus in the literature that a cultural fit between partners should exist in order for their collaboration to succeed (Meirovich, 2012). In international business literature, cultural similarity has received considerable attention as psychic closeness helps parties understand each other and build relationships (Saleh et al., 2014; Nes, Solberg \& Silkoset, 2007).

However, cultural similarity alone is insufficient for the relationship to bring about performance; relationship quality must be in place. Trust has been identified as a key aspect of the relational elements which can be affected by cultural similarity (Houjeir \& Brennan, 2017; MacDuffie, 2011). In the same way, Jarvenpaa et al. (1998) and Weber and Hsee (1998) also suggested that trust can be influenced by culture. Sharing similar cultures among parties in a transaction is a crucial prerequisite for building trust (Fritz \& Canavari, 2008). Thus, from a psychological perspective, trusting someone is to believe that the individual trusted will act as expected and trust is frequently associated with cultural similarity (Houjeir \& Brennan, 2017; Byrne, 1971). This is because similarities in language, level of education, business and cultural practices, and communication style will remove any cultural barriers while psychic closeness will minimize the degree of uncertainty in the new market, create trust between the parties involved and positively impact financial export results (Evans \& Mavondo, 2008).

Nevertheless, the fact that findings on cultural similarity and export performance relationship are inconclusive in previous literature suggests that some potential variables may come between the relationships. The IP theory, suggests that firms aim for culturally similar markets at the first stage of interntionalization before advancing to physically distant markets (Johanson \& Vahlne, 1977), signifying that similar cultural background across border relationship likely in influencing export performance (Castro \& Roldan, 2013). IP theory also recognizes that cultural similarity can facilitates communication and information sharing that in turn helps to build trust and contributes to increased commitment in the relationship. From the international perspective, in overcoming the barriers to perform and succeed in international exchange, trust plays a critical role such as becoming a mediator to counterbalance the potential harmful effects of culture (Nevins \& Money, 2008). Central to this approach, Kumar (1996) asserted that mutual trust between partners leads to greater profitability through improved performance, and better customer services and allows greater adaptability. This is because trust is the critical relational element and has become all the more salient (Sullivan \& Peterson, 1982) as it can play a key role in overcoming the challenges which finally reflect in export performance success. Nevertheless, previous findings are mixed which some scholars argued that trust can influence performance while others reported that trust has no significant relationship on performance (e.g., Houjeir \& Brennan, 2017; Nevin \& Money, 2008; Katsikeas, Skarmeas, \& Bello, 2009; Zaheer \& Kamal., 2011). As discussing in the literature, similarity of culture has a connection with trust and trust has a significant influence on performance. Following this notion, it is likely that cultural similarity is instrumental for the development of trust in SMEs, subsequently resulting in better export performance. This seems to imply that trust plays a significant central role in maintaining relationship quality which links cultural similarity to export performance. In other words, cultural similarity facilitates the creation of trust which then leads to enhanced_performance.

Despite general agreements on a range of explanatory variables, neither the nature of this fit nor the direction of cultural influence has been fully understood, due to the inconclusive results of empirical research. The issues of cultural similarity have received considerable attention in the IB 
literature for the impact on the function of cross-cultural buyer-seller interaction, communication and negotiation (Saleh et al., 2014). Some scholars argue that performance can increase when two partners possess similar cultural background and at the same time have different capabilities and resources (Sarkar, Echambadi, Cavusgil, and Aulakh (2001). Many authors also have emphasized the significance of cultural similarity in order for a merger to succeed (e.g., Noble, Gustafson, \& Hergert, 1988; Marks \& Mirvis, 1985) and for international cooperation to be fruitful (Hofstede, 1991). Behavioral norms and corporate practices may enhance cooperation, while cultural differences may lead to alienation, uncertainty and problems of adjustment (Dauber, 2012). Based on these themes, cognitive dissonance theory (Aronson \& Carlsmith, 1962; Festinger, 1957) states that people prefer information that is in-line and supports their attitudes and behavior and this stand creates some biasness when obtaining data that substantiates their beliefs (Fiske \& Taylor, 1984).

At the same time, other findings have led to the opposite conclusion. Some studies have produced contrasting findings which found that the performance of IJVs has a positive correlation with national cultural distance (Park \& Ungson, 1997). A study conducted by Pothukuchi et al. (2002) also found that cultural distance positively impacts efficiency and performance. Research conducted by Krishnan, Miller, \& Judge, (1997); Morosini, Shane, \& Singh (1998) also found that larger cultural distance is associated with better performance. Similar results were reached in the study of another type of inter-organizational relationship which is mergers and acquisitions found that US-Japanese partnerships tend to be sustained better than US-US ones (Lubatkin, Scweiger, $\&$ Weber, 1999). Additionally, Schweiger and Goulet (2005) maintained that parties to a partnership that are pushed too far in terms of similarity can fear the loss of identity These findings imply that cultural fit may not necessarily mean being alike - it may mean being complementary, that is, different from each other (Meirovich, 2012). Though these arguments are certainly not without merits, there are also other reasons for these inconsistent in findings. This conflicting result may cause by the multilevel nature of culture, the varying concept of the methodology and the fact that economic and psychological performance are in congruent (Pothukuchi et al., 2002). Thus, it is relevant and timely for this study to examine by which cultural similarity can bring about performance from the perspectives in Asian emerging market.

\section{Trust, commitment and cooperation}

Majority of previous studies found that trust as a central factor in explaining buyer-seller relationships either as explanatory variable or a criterion variable (Saleh et al., 2014). According to Morgan and Hunt (1994), trust can be defined a belief in the exchange partner's dependability and honesty based on the understanding that the other party to the relationship will not take the opportunity to exploit a situation for self-interest. Relationship literature acknowledged that trust has a central role in maintaining, developing and upholding long-term inter-firm relationship. In this study, cultural similarity is also anticipated as an essential factor that can facilitate trust in the relationship between exporters and intermediaries. The creation and nurturing of trust is very important for developing effective and efficient social network applications. This has been studied from various perspectives including from the social context (Trifunovic, Legendre, Herlocker, \& Sen, 2010). Nevertheless, one lesser explored issue is how trust is established in a dynamic relationship across borders, which has also been not empirically tested (Hayashi \& Kryssanov, 2013). Studies by Byrne (1971) in social psychology revealed that there is a relationship between similarity and trust while experiments carried out by Golbeck (2009) assert that similarity has a significant relationship with the user's determinant to trust each other. As claimed by Kanter and 
Corn (1994), foreign buyers and sellers tend to opt for markets that have cultural similarities for long-term relationships, which in turn, may result in the generation of trust for long-term business gain. Meanwhile, Amelung (1994) suggested that if there are cultural similarities between parties across cultures, it will reduce operation costs and lead to the building of trustworthy relationships. Additionally, prior studies have mostly advocated that exporters stand a better chance of being trusted and accepted by their partners in foreign markets that have cultural similarities.

In a classical study by Spekman (1988), it is claimed that trust is "the cornerstone of a strategic partnership" and can be a crucial factor in developing an acceptable long-term relationship with a business partner (Dwyer et al., 1987). Ruyter, Moorman, and Lemmink (2001) viewed trust between partners as a crucial factor in any business activity that encourages the parties concerned to pay more attention to the "positive" motivation of affiliation as an important asset to gain appropriate resources such as information, technology, knowledge, access to distribution network and so forth to compete effectively in foreign markets. This is because trust can generate competitive advantage (Yli- Renko Autio \& Sapienza, 2001) and plays an integral role in a company. More importantly, development of trust is very crucial to generate commitment of potential channel members at the onset of a new relationship to guarantee higher group performance, and increased job satisfaction. According to Gulati and Singh (1998), when trust is absent, there will be neither collaboration nor any relational benefits. At the heart of the trustdevelopment challenge is the acceptance of vulnerability (Ring \&Ven, 1992) as building a high level of trust and relational embeddedness can be both expensive and challenging.

Most researchers have reported that trust is a positive and important indicator of buyer-seller commitment (Saleh \& Ali, 2009). Previous literature has also supported that trust increases commitment, which then leads to cooperation (Inkpen \& Currall, 2004). Despite several studies referring to the conceptual relationship between the constructs of trust and commitment (e.g. Saleh et al., 2014; Pinho, 2013, Saleh \& Ndubisi, 2006), scholars disagree of trust and commitment relationship. For example, Tellefsen and Thomas (2005) argued that the link between trust and commitment has not been fully examined or tested in the literature and follow-up studies have been confined to only a small set of factors and findings which are inconsistent (Liu, Li, \& Zhang, 2010). In line with Geyskens et al. (1996) has found mixed results between trust and commitment. Therefore, they called for more research as evidence to quantify the relationship and offer more verification of the significant influence of the relationship between trust and commitment. The importance of relationship commitment stems from the fact that it will probably lead to cooperative behavior, minimize or eliminate the likelihood of tempting short-term alternatives, and improve the profit margins (Andaleeb, 1996; Anderson \& Weitz, 1992; Morgan \& Hunt, 1994). A party involved in a partnership will be cooperative, motivated by an aspiration to work on the relationship and make it succeed (Anderson \& Narus 1990).

Haahti et al. (2005) found that firms forge cooperation due to the intense desire to compete effectively in foreign markets and reap the benefits of synergy that can enable the intense exchange of market information and valuable knowledge (Amble \& Styles, 2000). Anderson and Narus (1990) also agreed with this suggestion and supported the notion that genuine cooperative behavior exhibited by genuine partners is crucial, which leads to all the parties' involved reaping mutual benefit. On the contrary, some studies were unable to verify the advantages of cooperation. Hence, some studies have indicated that cooperation has a significant relationship with performance, while other scholars have indicated a weak relationship between these two constructs. For example, 
Vereecke and Muylle (2006) investigated the cooperation between suppliers and customers and found that these two variables were remotely related. According to Fynes, Voss, and Burca (2005), only a partial relationship exists for the impact of supply chain relationships on cooperation and performance. Villena, Revilla, and Choi (2011) also produced a U - shaped relationship between social capital elements (e.g., cooperation) and performance and noted that too much cooperation may have a negative effect on performance. Turnbull, Oliver, and Wilkinson (1992) found no significant relationship between cooperation and performance due to difficulties faced by a United Kingdom company and Japanese practices. Burnes and New (1997) strongly defended the relationship context and were not confident with the exaggerated effects of these two variables. Therefore, according to these discussions, this study provides further evidence to verify the relationship between exporters and intermediaries and attempts to provide more indications of the impact of cooperation and performance on export markets. Therefore, for a more detailed examination of these issues that were substantiated by concrete depositions in the literature, the following hypotheses were proposed:

H1: There is a positive relationship between cultural similarity and export performance

H2: There is a positive relationship between cultural similarity and trust

H3: There is a positive relationship between trust and commitment.

H4: There is a positive relationship between trust and cooperation

H5: There is a positive relationship between commitment and cooperation.

H6: There is a positive relationship between cooperation and export performance

H7: There is a positive relationship between trust and export performance.

H8: Trust mediates the relationship between cultural similarity and export performance.

Figure 2: Conceptual Framework

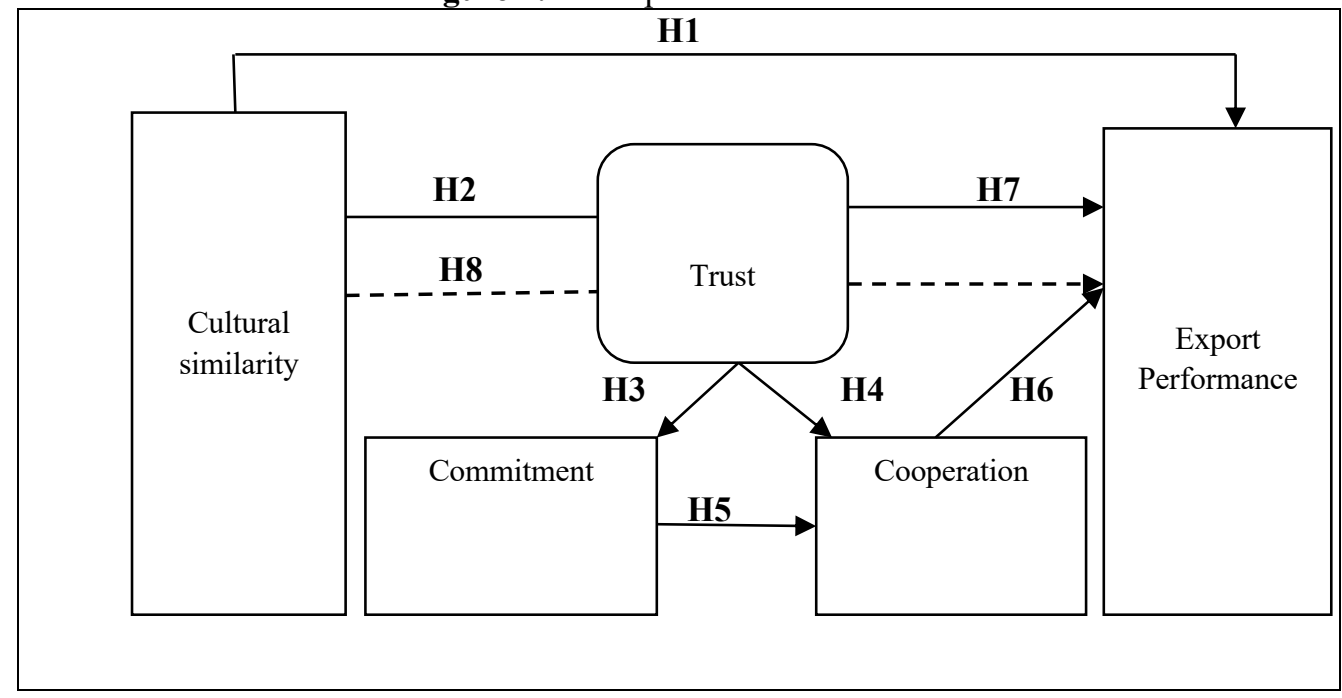

Drawing on the above theoretical discussion, this study integrates cultural similarity, trust, commitment, cooperation and export performance in a comprehensive framework. The proposed 
framework (Figure 2) specifies path relationships between the antecedents in the trust and export performance building process.

\section{RESEARCH METHODOLOGY}

This section provides and justifies the method used in this research, including the research design and research instrument.

\subsection{Research Design and Instrument Development}

In this study, a mailed survey design was used for testing the research model. Top management such as Chief Executive Officers (CEOs), managers or officers of SMEs are the key informer and could not be accessed via other methods (Bartholomew \& Smith, 2006). The sample elements were taken from MATRADE and SME Corporation databases. A total of 14,000 SME firms of various product categories were found from the MATRADE database. Target respondents had to possess two important criteria: (1) SME manufacturing firms in Malaysia involved in exporting; and (2) SME manufacturing firms that use intermediary services (e.g., agent, distributor and sales representatives). After crosschecking with SME Corporation database, a total 1,000 SME manufacturing firms fulfilled the requirements set for this study. Thus, the working population of this study was 1,000 SME firms. The questionnaire was posted to all targeted respondents, and follow-up was done by phone call and email.

A quantitative method was used in this study and the measurement items were obtained from relevant literatures. For this study, the constructs were measured using a 7-point Likert scale, ranging from $1=$ strongly disagree to $7=$ strongly agree except for export performance which used $1=$ much below expectation to $7=$ much above expectation. Five constructs were measured in this study. For cultural similarity, five measurements items were borrowed from Saleh et al. (2014), i.e., manner of greetings, business practices, legal formalities, ethics and value and business contract. Nine items were borrowed from Pinho (2013) for trust. Concerning the relationship commitment construct, it was measured using seven items adopted from Morgan and Hunt (1994). Similarly, for the cooperation construct, five items were adapted from Morgan and Hunt (1994). Meanwhile, for export performance measurement, six items were adopted from previous studies. In this study, trust serves as a mediator between cultural similarity and export performance.

\subsection{Survey and Response Rate}

A survey package contains questionnaire in English and Malay versions and a reply paid selfaddressed envelope was posted to the 1,000 respondents fulfilled the criteria as mentioned earlier in this study. After two rounds of follow-up calls and email reminders, a total of 232 responses were received. Nevertheless, only 203 responses were found to be usable and retained for further analysis, with 29 responses being discarded due to incomplete responses in some important sections. Most of the respondents were managers of SME firms. 


\section{DATA ANALYSIS AND FINDINGS}

Statistical Package for Social Sciences (SPSS v. 23) and Partial Least Squares (PLS) with smart PLS 2.0 (Hair et al., 2012) were used for data analysis. Table 1 presents the respondents' profile. It indicates that there are an almost equal number of male (101) and female (102) respondents. Majority of the respondents are in the 31-50 age groups. They are either owner or top personal or managers (General Manager, director, manager and commercial officer). Table 1 also shows that respondents with bachelor's degree (46.3\%) dominated the survey.

Table 1: Respondent Profile

\begin{tabular}{lcc}
\hline \hline \multicolumn{1}{c}{ Demographic Features } & Frequency & Percentage \\
\hline Gender & 101 & 49.8 \\
Male & 102 & 50.2 \\
Female & & \\
\hline Age & 55 & 27.1 \\
30 years and below & 62 & 30.5 \\
31 to 40 years & 60 & 29.6 \\
41 to 50 years & 26 & 12.8 \\
Above 50 years & & \\
\hline Designation & 24 & 11.8 \\
Owner of the firm & 0 & 0 \\
Managing Director & 1 & 0.05 \\
Chief Executive Officer (CEO) & 12 & 5.9 \\
General Manager & 12 & 5.9 \\
Director & 71 & 35.0 \\
Manager & 52 & 25.6 \\
Commercial officer & 31 & 15.3 \\
Others & & \\
\hline Level of Qualification & 25 & 12.3 \\
School certificate & 11 & 5.4 \\
Professional Certificates & 60 & 29.6 \\
Diploma & 94 & 46.3 \\
Bachelor Degree & 11 & 5.4 \\
Masters & 0 & 0 \\
PhD & 2 & 5.4 \\
Others & & \\
\hline \hline
\end{tabular}

Reliability and validity assessments were conducted to analyze the measurement model. The result indicates that the level of composite reliability (CR) were more than 0.7 for all constructs. Convergent validity and discriminant validity were performed to assess the validity of the constructs. The analysis (Table 2) indicates that the value of Average Variance Extracted (AVE) was greater than 0.5 for all constructs (Fornell \& Larcker, 1981). Further, discriminant validity (Table 3) was established in this study since the square roots of AVE were higher than its correlation compared to the other constructs. 
Table 2: Measurement Model: Factor loadings, CR and AVE

\begin{tabular}{|c|c|c|c|c|}
\hline Model construct & Measurement item & Loadings & AVE & $\mathbf{C R}$ \\
\hline \multirow{5}{*}{ Cultural Similarity } & $\mathrm{B} 8 \mathrm{a}$ & 0.782 & \multirow{5}{*}{0.685} & \multirow{5}{*}{0.915} \\
\hline & $\mathrm{B} 8 \mathrm{~b}$ & 0.848 & & \\
\hline & $\mathrm{B} 8 \mathrm{c}$ & 0.844 & & \\
\hline & B8d & 0.848 & & \\
\hline & B8e & 0.815 & & \\
\hline \multirow{9}{*}{ Trust } & C11a & 0.827 & \multirow{9}{*}{0.693} & \multirow{9}{*}{0.953} \\
\hline & $\mathrm{C} 11 \mathrm{~b}$ & 0.861 & & \\
\hline & $\mathrm{C} 11 \mathrm{c}$ & 0.864 & & \\
\hline & C11d & 0.846 & & \\
\hline & $\mathrm{C} 11 \mathrm{e}$ & 0.853 & & \\
\hline & C11f & 0.865 & & \\
\hline & C11g & 0.837 & & \\
\hline & $\mathrm{C} 11 \mathrm{~h}$ & 0.669 & & \\
\hline & $\mathrm{C} 11 \mathrm{i}$ & 0.850 & & \\
\hline \multirow{7}{*}{ Commitment } & $\mathrm{C} 12 \mathrm{a}$ & 0.849 & \multirow{7}{*}{0.678} & \multirow{7}{*}{0.936} \\
\hline & $\mathrm{C} 12 \mathrm{~b}$ & 0.799 & & \\
\hline & $\mathrm{C} 12 \mathrm{c}$ & 0.781 & & \\
\hline & C12d & 0.852 & & \\
\hline & $\mathrm{C} 12 \mathrm{e}$ & 0.818 & & \\
\hline & $\mathrm{C} 12 \mathrm{f}$ & 0.819 & & \\
\hline & $\mathrm{C} 12 \mathrm{~g}$ & 0.844 & & \\
\hline \multirow{5}{*}{ Cooperation } & $\mathrm{C} 13 \mathrm{a}$ & 0.772 & \multirow{5}{*}{0.684} & \multirow{5}{*}{0.915} \\
\hline & $\mathrm{C} 13 \mathrm{~b}$ & 0.852 & & \\
\hline & $\mathrm{C} 13 \mathrm{c}$ & 0.787 & & \\
\hline & C13d & 0.881 & & \\
\hline & $\mathrm{C} 13 \mathrm{e}$ & 0.838 & & \\
\hline \multirow{6}{*}{ Export Performance } & D15a & 0.907 & \multirow{6}{*}{0.781} & \multirow{6}{*}{0.956} \\
\hline & $\mathrm{D} 15 \mathrm{~b}$ & 0.894 & & \\
\hline & $\mathrm{D} 15 \mathrm{c}$ & 0.896 & & \\
\hline & D15d & 0.888 & & \\
\hline & $\mathrm{D} 15 \mathrm{e}$ & 0.874 & & \\
\hline & $\mathrm{D} 15 \mathrm{f}$ & 0.845 & & \\
\hline
\end{tabular}

Note: ${ }^{\mathrm{x}}$ Composite Reliability $(\mathbf{C R})=$ (square of the summation of the factor loadings) / [(square of the summation of the factor loadings) + (square of the summation of the error variances)]. ${ }^{\text {y Average }}$ Variance Extracted (AVE) $=($ summation of the square of the factor loadings) / [(summation of the square of the factor loadings) + (summation of the error variances)]

Table 3: Discriminant Validity

\begin{tabular}{cccccc}
\hline \hline $\begin{array}{c}\text { Latent } \\
\text { Construct }\end{array}$ & Commitment & Cooperation & $\begin{array}{c}\text { Cultural } \\
\text { similarity }\end{array}$ & $\begin{array}{c}\text { Export } \\
\text { Performance }\end{array}$ & Trust \\
\hline COM & $\mathbf{0 . 8 2 3}$ & & & & \\
COO & 0.692 & $\mathbf{0 . 8 2 8}$ & & & \\
CS & 0.455 & 0.396 & $\mathbf{0 . 8 2 8}$ & $\mathbf{0 . 8 8 4}$ & \\
EXP & 0.394 & 0.462 & 0.233 &
\end{tabular}




\begin{tabular}{cccccc}
\hline \hline $\begin{array}{c}\text { Latent } \\
\text { Construct }\end{array}$ & Commitment & Cooperation & $\begin{array}{c}\text { Cultural } \\
\text { similarity }\end{array}$ & $\begin{array}{c}\text { Export } \\
\text { Performance }\end{array}$ & Trust \\
\hline TR & 0.731 & 0.697 & 0.469 & 0.403 & $\mathbf{0 . 8 3 2}$ \\
\hline \hline
\end{tabular}

Note: Diagonal indicates $\sqrt{ } \mathrm{AVE}$; off diagonal indicates correlations between constructs: Where, COM=Commitment, $\mathrm{COO}=$ Cooperation, $\mathrm{CS}=\mathrm{Cultural}$ Similarity, $\mathrm{TR}=$ Trust and export performance.

For the purposes of hypothesis testing, the structural model was performed. The bootstrapping technique was used to test the significance of weighting. The proposed mediating effect relied on Preacher and Hayes (2008) and used non-parametric bootstrapping. Table 4 presents the path coefficient assessment related to this study. The results depicted that all hypotheses were supported and trust (Table 5) was confirmed as having a mediation effect in the relationship between cultural similarity and export performance.

Table 4: Path Co-efficient Assessment

\begin{tabular}{llccccc}
\hline Hypotheses & Path/Relationship & \multicolumn{3}{c}{ SEM Output-Full Model } & \\
& & B & SE & T & P & \\
\hline H1 & CS-EXP & 0.207 & 0.033 & 6.287 & $\mathrm{P}<0.01$ & Supported \\
H2 & CS-TR & 0.469 & 0.036 & 13.06 & $\mathrm{P}<0.01$ & Supported \\
H3 & TR-COM & 0.731 & 0.019 & 37.14 & $\mathrm{P}<0.01$ & Supported \\
H4 & TR-COO & 0.697 & 0.024 & 29.03 & $\mathrm{P}<0.01$ & Supported \\
H5 & COM-COO & 0.393 & 0.064 & 6.127 & $\mathrm{P}<0.01$ & Supported \\
H6 & COO-EXP & 0.345 & 0.044 & 7.854 & $\mathrm{P}<0.01$ & Supported \\
H7 & TR-EXP & 0.036 & 10.87 & $\mathrm{P}<0.01$ & & Supported \\
\hline \hline
\end{tabular}

Table 5 indicates that $\mathrm{H} 8$ is supported with variance accounted for (VAF) of 0.739 with T-value is 8.44, showing that trust has a significant influence in the relationship between cultural similarity and export performance.

Table 5: Mediation Result

\begin{tabular}{lllll}
\hline \hline Hypothesis & Path/Relationship & VAF & T & Result \\
\hline H8 & CS-TR-EXP & 0.739 & 8.44 & Partial Mediation \\
\hline \hline
\end{tabular}

\section{DISCUSSION AND CONCLUSION}

In this study, H1 hypothesized a positive relationship between cultural similarity and export performance. It clearly shows that similar cultural background of exporter and intermediary can influence export profitability. This study is consistent with previous studies conducted by Azar (2014) who noted that succeed in international business proceed by partners having cultural similarity. In line with internationalization literature, cultural closeness between partners can lead to the best performance of firms in the international arena. This is because exporters and intermediaries can minimize the risk of distrust and conflict since they possess similarity in terms of language, environment and business format. Indeed, in SME intermediary context, cultural 
similarity is important for developing a high quality relationship between exporters and intermediaries to ensure success in foreign markets as well as to enhance performance of SME firms particularly for initial growth stages.

Similarly, $\mathrm{H} 2$ and $\mathrm{H} 3$ were supported for their positive relationship. This confirmed that cultural similarity between exporter and intermediary has a significant influence on trust $(\mathrm{H} 2)$. Trust between exporter and intermediary also has a positive effect on commitment (H3). This indicates that when exporters and intermediaries come from a similar cultural background, it can make the relationship grow and can increase the understanding between both partners, which impact trust. Thus, as supported by Kabadayi and Lerman (2011) in previous studies, cultural similarity is a fundamental factor for trust development among business partners. Besides, with regard to $\mathrm{H} 3$, the findings reveal that trust has a positive relationship with commitment, indicating that trust is a critical and ongoing process to improve export performance. Based on this scenario, trust is identified as a predictor of commitment. This result is in line with the findings by Saleh et al. (2014); Ruyter et al. (2001) and Chen et al. (2016).

The study also found support for $\mathrm{H} 4, \mathrm{H} 5, \mathrm{H} 6$ and $\mathrm{H} 7$ for their positive relationships. This suggests that trust has a significant influence on cooperation (H4) in the relationship between exporter and intermediary. This outcome offers insights that when exporters and intermediaries trust each other, they are more enthusiastic about cooperating to share strategic market information without having to worry that they might be exploited by the other party (Pinho, 2013). Specifically, choosing a reliable intermediary is of great importance as it can help to give a sense of authenticity to access relevant resources such as financial resources. H5 in this study is on the relationship between commitment and cooperation of exporter and intermediary. The results show that commitment can influence the degree of cooperation between exporter and intermediary. For example, when exporter and intermediary can commit to each other, it can facilitate them to bundle their resources and cooperate to be successful in the international market. This study is in line with previous findings (e.g., Pinho, 2016; Fink, Harms, \& Kraus, 2008) which claim that a committed relationship between exporters and intermediaries will extend to cooperation and a desire to make the relationship works (Morgan \& Hunt, 1990).

Subsequently, H6 stated that greater cooperation between exporters and intermediaries ultimately can enhance export performance. The result depicted that the level of export performance was significant influenced by cooperation. Surprisingly, the current findings contradict some previous studies that have failed to validate the relationship between cooperation and export performance which produce inconsistencies in findings. For instance, Prahinski and Benton (2004) found that there is no link between cooperative buyers and supplier relationships and suppliers' performance. Meanwhile, Fyness et al. (2005) found partial support for the impact of supply chain relationships between cooperation elements and performance. Further, Villena et al. (2011) found a U-shape relationship between cooperation and performance. This happens due to differences in terms of industry structure, context and how the cooperation has been operationalized, which in turn, have contributed to inconclusive findings. However, this finding concurred with Racela et al. (2007) who asserted that a cooperative relationship can facilitate export success. Similarly, H7 was supported; the finding shown that trust has a significantly positive relationship with export performance in the context of exporter and intermediary. The result is in tandem with previous studies which have noted that trust significantly contributes to competitiveness in foreign markets (e.g., Lehtinen et al., 2016; Hador, 2017). Also, the presence of trust is seen as being able to lower 
transaction costs and improve investment in relationship-specific assets and superior information sharing routines (Dyer \& Chu, 2011).

Finally, H8 hypothesize on the intervening effect of trust in the relationship between cultural similarity and export performance. The result demonstrated that trust serves as a mediator to link cultural similarity and export performance. This suggests that if the partner comes from a similar cultural background, it simplifies the relationship, particularly in establishing trust elements in business dealings and indirectly improves the exporter's export performance (Houjeir \& Brennan, 2017; Lehtinen et al., 2016). This finding seems interesting and relevant in the context of the relationship between exporters and intermediaries because in the Malaysian context, trust and relational elements have been noted to be really important and stronger compared to the Western context (Behyan et al., 2011). As a conclusion, cultural similarity is indeed important for its role in improving relationship quality between exporters and intermediaries, which in turn, will be manifested in higher export performance.

\section{CONTRIBUTIONS, LIMITATIONS AND FUTURE DIRECTIONS}

This study made several contributions to existing theoretical knowledge and managerial implications. First, it extends the use of Internationalization Process (IP) theory which was popularized by Johanson and Vahlne (1977). This study support the notions of IP theory which posited that cultural similarity can reduce some obstacles in foreign market such as miscommunication, distrust and misinformation between business partner and it can help to create mutual understanding to build high quality relationship which finally reflect in the performance outcome. Second, the result enriched the application of the Relational Exchange Theory (RET) in explaining inter-organizational learning as a valuable asset which will contribute to the export success. More importantly, the results support the notion of RET's application in SME exporters' context. From practical perspective, it offers a very useful guideline to suggest that cultural similarity is relevance for SME's export managers to consider when identifying their foreign intermediaries. It clearly shows that trust is a key element in cross border relationship and SME manager should develop trust for nurturing a high quality relationship with their foreign intermediaries which can influence the export success. In addition, SME export managers also should concentrates on relational factors such as trust, commitment and cooperation in developing high quality relationship for exchanging resources such as knowledge and experience with their foreign intermediaries to enhance export performance.

Despite its importance, there are several limitations inherent in this study. This study only looks solely from SME exporters view without considering intermediaries perspective. Therefore, future studies are encouraged to take into account both sides. Furthermore, this study concentrates on manufacturing companies rather than services industries, limiting the findings to manufacturing sector. It is therefore suggested that future research can investigate both manufacturing and service firms to obtain more holistic picture and bigger view. In addition, this study employs crosssectional approach. Thus, future research is suggested to use longitudinal study to determine if there will be different outcomes and findings. In conclusion, findings of the study have addressed the research hypotheses and validated the relationships of all constructs under study. Additionally, trust was confirmed as a mediator in the relationship between cultural similarity and export performance which has not been extensively researched previously. 


\section{ACKNOWLEDGEMENT}

I would like to express my deepest gratitude to Allah S. W. T that makes me move forward to complete this research paper. First of all I would like to express my deep feeling of gratitude to Associate Professor Dr Serene Ng Siew Imm who has inspired me to complete this research paper. My specials thank goes to Universiti Malaysia Sarawak (UNIMAS) for giving me the opportunity to publish my research paper in International Journal of Business and Society (IJBS). Finally, my sincere thanks go to my beloved parents, family and all people who have contributed directly or indirectly to complete this research paper. Praise to Allah. Alhamdullilah.

\section{REFERENCES}

Agndal, H., Chetty, S., \& Wilson, H. (2008). Social capital dynamics and foreign market entry. International Business Review , 17(6), 663-675.

Ahmadian, S. (2012). International Opportunity Recognition and Export Satisfaction in SMEs through Export Intermediary Networking. (Doctoral dissertation, The Universiti of Teknologi Malaysia. Johor, Malaysia). Retrived from http://eprints.utm.my/id/eprint321975.

Ambler, T., \& Styles, C. (2000). The future of relational research in international marketing: Constructs and conduits. International Marketing Review, 17 6), 492-508.

Amelung, T. (1994). The Impact of Transaction Costs on Trade Flows in the Asia Pacific. Asia Pacific Regionalism: Readings in International Economic Relations. Sydney: Harper Collins.

Andaleeb, S. S. (1996). An experimental invesigation of satisfaction and commitment in marketing channels: The role of trust and dependence. Journal of Retailing , 72(1), 77-93.

Anderson, J. C., \& Narus, J. A. (1990). A model of distributor firm and manufacturer firm working partnerships. Journal of Marketing , 54 (1), 42-58.

Anderson, E., \& Weitz, B. (1992). The use of pledges to build and sustain commitment in distribution channels. Journal of Marketing Research , 29(1), 18-34.

Aronson, E., \& Carlsmith, J. M. (1962). Performance expectancy as a determinant of actual performance. Journal of Abnormal and Social Psychology , 65(3), 178-182.

Azar, G. (2014). Food cultural distance as a predictor of foreign market selection: The case of Swedish food exporters. Journal of Foods Products Marketing , 20(1), 75-97.

Balabanis, G. I. (2000). Factors affecting export intermediaries service offerings: The British example. Journal of International Business Studies , 31(1), 83-99.

Behyan, M., Mohamad, O., \& Omar, A. (2011). Achieving export performance: Contribution of relational elements. Journal of Social and Behavioral Sciences , 25(2011), 327-337.

Bloemer, J., pluymaekers, M., \& Odekerken, A. (2013). Trust and effective commitment as energizing forces for export performance. International Business Review , 22(2013), 363380.

Boyacigiller, N. (1990). The role of expatriates in the management of interdependence complexity and risks in multinational corporations. Journal of International Business Studies , 21(3), 357-381.

Burnes, B., \& New, S. (1997). Collaboration in customer-supplier relationships: Strategy, operations and the function of rhetoric. International Journal of Purchasing and Materials Management, 33(4), 10-17. 
Byrne, D. (1971). The Attraction Paradigm. New York: Academic Press.

Castro, I., \& Roldan, J. L. (2013). A mediation model between dimensions of social capital. International Business Review , 22(6), 1034-1050.

Cavusgil, S. T., \& Zou, S. (1994). Marketing strategy-performance relationship: An investigation of the empirical link in export market ventures. Journal of Marketing , 58(1), 1-21.

Chen, J., Sousa, C. M., \& He, X. (2016). The determinants of export performance: A review of the literature 2006-2014. International Marketing Review , 33(5), 626-670.

Dauber, D. (2012). Opposing positions in M\&A research: Culture, integration and performance; cross cultural management. An International Journal , 19(3), 375-398.

Department of Statistic Malaysia (2015). The Census of Establishment and Enterprises 2015. Department of Statistic Malaysia, Kuala Lumpur, Malaysia

Department of Statistic Malaysia (2017). The Census of Establishment and Enterprises 2017. Department of Statistic Malaysia, Kuala Lumpur, Malaysia

Dwyer, F. R., Schurr, P. H., \& Oh, S. (1987). Developing buyer-seller relationships. Journal of Marketing , 51(2), 11-27.

Erdil, T. S. (2014). The role of foreign intermediary relationship quality on export performance: A survey on Turkish firms. Procedia Social and Behavioral Sciences, 150(15), 600-608.

Evans, J., Mavondo, F. T., \& Bridson, K. (2008). Psychic distance: Antecedents, retail strategy implications, and performance outcomes. Journal of International Marketing , 16(2), 3263.

Festinger, L. (1957). A Theory of Cognitive Dissonance. Evanston, IL: Row, Peterson.

Fink, M., Harms, R., \& Kraus, S. (2008). Cooperative internationalization of SMEs: Selfcommitment as a success factor for International Entrepreneurship. European Management Journal , 26(6), 429-440.

Fiske, S. T., \& Taylor, S. E. (1984). Social Cognition Reading. MA: Addison-Wesley.

Fornell, C., \& Larcker, D. F. (1981). Evaluating structural equation models with unobservable variables and measurement error. Journal of Marketing Research , 18(1), 39-50.

Frazier, G. L., Gill, J. D., \& Kale, S. H. (1989). Dealer dependence levels and reciprocal actions in a channel of distribution in a developing country. Journal of Marketing, 53(1), 50-69.

Fritz, M., \& Canavari, M. (2008). Management of perceived e-business risks in food-supply networks: E-trust as prerequisite for supply-chain system innovation. Agribusiness an International Journal , 24(3), 355-368.

Fynes, B., Voss, C., \& Burca, S. D. (2005). The impact of supply chain relationship dynamics on manufacturing performance. International Journal of Operations \& Production Management , 25(1), 6-19.

Geyskens, I., Steenkamp, J.-B. E., Scheer, L. K., \& Kumar, N. (1996). The effects of trust and interdependence on relationship commitment: A trans-Atlantic study. International Journal of Research in Marketing , 13(4), 303-317.

Golbeck, J. (2009). Trust and nuanced profile similarity in online social networks. $A C M$ Transactions on the Web (TWEB) , 3(4), 1-33.

Gulati, R., \& Singh, H. (1998). The architecture of cooperation: managing coordination costs and appropriation concerns in strategic alliances. Administrative Science Quarterly, 43(4), 781-814.

Haahti, A., Madupu, V., Yavas, U., \& Babakus, E. (2005). Cooperative strategy, knowledge intensity and export performance of small and medium sized enterprises. Journal of World Business , 40(2), 124-138. 
Hador, B. B. (2017). Three levels of organizational social capital and their connection to performance. Journal of Management Development, 36(3), 348-360.

Hair, J. F., Sarstedt, M., Ringle, C. M., \& Mena, J. A. (2012). An assessment of the use of Partial Least Squares Structural Equation modeling in marketing research. Journal of the Academy of Marketing Science , 40(3), 414- 433.

Hayashi, Y., Kryssanov, V., \& Ogawa, H. (2013). An Empirical Investigation of Similarity Driven Trust Dynamics in a Social Network. In International Conference on Human computer Interaction (pp. 20-28). Springer, Berlin. Heidelberg.

Hofstede, G. (1991). Cultures and Organizations: Software of the Mind. London, UK: McGrawHill.

Houjeir, R., \& Brennan, D. (2017). The influence of culture on trust in B2B banking relationships. International Journal of Bank Marketing , 35(3), 551-566.

Hunt, C. C. (2000). What have we learned about generic competitive strategy? A meta-analysis. Strategic Management Journal, 127-154.

Inkpen, A. C., \& Currall, S. C. (2004). The coevolution of trust, control and learning in joint ventures. Organisation Science, 15(5), 586 - 599.

Jarvenpaa, S. L., \& Leidner, D. E. (1998). An information company in Mexico: Extending the Resource-Based View of the firm to a developing country context. Information Systems Research, 9(4), 342 - 361.

Jeong, H. W. (2017). Peace and Conflict Studies: An Introduction. Routledge, New York: Tailor \& Francis.

Johanson, J., \& Vahlne, J.-E. (1977). The Internationalization Process of the firm-A model of knowledge development and increasing foreign market commitments. Journal of International Business Studies , 8 (1), 23-32.

Kabadayi, S., \& Lerman, D. (2011). Made in China but sold at FAO Schwarz: Country-of-origin effect and trusting beliefs. International Marketing Review , 28(1), 102-126.

Kanter, R. M., \& Corn, R. I. (1994). Do cultural differences make a business difference?: Contextual factors affecting cross-cultural relationship success. The Journal of Management Development, 13(2), 5-23.

Katsikeas, C. S., Skarmeas, D., \& Bello, D. C. (2009). Developing successful trust-based international exchange relationships. Journal of International Business Studies, 40(1), $132-155$.

Klein, S., \& Roth, V. J. (1990). Determinants of export channel structure: The effects of experience and psychic distance reconsidered. International Marketing Review , 7(5), 27-38.

Kulhmeier, B., \& David, G. K. (2010). The critical of relationship quality in small and medium sized enterprise internationalization. Journal of Global Marketing , 23(2010), 16-32.

Kumar, N. (1996). The power of trust in manufacturer-retailer relationship. Harvard Business Review , 74 (November-December), 92-106.

Kumar, R., \& Singh, R. K. (2017). Coordination and responsiveness issues in SME supply chains: a review. Benchmarking: An International Journal , 24(3), 635-650.

Lehtinen, U., Ahokangas, P., \& Lu, J. (2016). The role of intermediaries in food export: Case evidence from Finland. British Food Journal, 118 (5), 1179-1194.

Leonidou, C. N., Leonidou, L. C., Coudounaris, D. N., \& Hultman, M. (2013). Value differences as determinants of importers' perceptions of exporters' unethical behavior: The impact on relationship quality and performance. International Business Review, 22 (1), 156-173.

Liu, Y., Li, Y., \& Zhang, L. (2010). Control mechanisms across a buyer-supplier relationship quality matrix. Journal of Business Research, 63(1), 3-12. 
Lubatkin, M. (1999). Top management turnover in related M\&A's: An additional test of the theory of relative standing. Journal of Management, 25(1), 55-73.

MacDuffie, J. P. (2011). Inter-organizational trust and the dynamics of distrust. Journal of International Business Studies, 42(1), 35-47.

Malaysia External Trade Development Corporation [MATRADE] (2014, December 18). MATRADE Media Release: MATRADE gearing up for 2014 with new initiatives to expand SMEs export. Retrieved from MATRADE: http:/www.matrade.gov.my

Malaysia External Trade Development Corporation [MATRADE] (2018, May 21). SMEs need to look at export market. Retrieved from MATRADE: http://www.matrade.gov.my.

Marks, M. L., \& Mirvis, P. H. (2001). Making mergers and acquisitions work: Strategic and psychological preparation. Academy of Management Executives , 15(2), 80-94.

Meirovich, G. (2012). Cultural similarities and differences: Impacts on performance in strategic partnership. In Advances in Mergers and Acquisitions, 10, 55-74.

Morgan, R. M., \& Hunt, S. D. (1994). The commitment-trust theory of relationship marketing. Journal of Marketing, 58(3), 20-38.

Morgan, N. A., Vorhies, D. W., \& Schlegelmilch, B. B. (2006). Resource-performance relationships in industrial export ventures: The role of resource inimitability and substitutability. Industrial Marketing Management, 35(5), 621-633.

Musteen, M., Francis, J., \& Datta, D. K. (2010). The influence of international networks on internationalization speed and performance: A study of Czech SMEs. Journal of World Business, 45(3), 197-205.

Navarro, A., Losada, F., Ruzo, E., \& Díez, J. A. (2010). Implications of perceived competitive advantages, adaptation of marketing tactics and export commitment on export performance. Journal of World Business, 45(1), 49-58.

Nes, E. B., Solberg, C. A., \& Silkoset, R. (2007). The impact of national culture and communication on exporter-distributor relations and on export performance. International Business Review, 16(4), 405-424.

Nevins, J. L., \& Money, R. B. (2008). Performance implications of distributor effectiveness, trust, and culture in import channels of distributions. Industrial Marketing Management, 37(1), 46-58.

Noble, A. F., Gustafson, L. T., \& Hergert, M. (1988). Planning for post-merger integration-eight lessons for merger success. Long Range Planning, 21(4), 82-85.

Obadia, C. (2010). Benefits-based drivers of exporters' attitudinal commitment toward their foreign. International Marketing Review, 27(6), 606-629.

Park, S. H., \& Ungson, G. R. (1997). The effect of national culture, organizational complememtarity, and economic motivation on joint venture dissolution. Academy of Management Journal, 40(2), 279-307.

Pinho, J. C. (2016). Social capital and export performance within exporter-intermediary relationships. Management Research Review, 39(4), 425 - 448.

Pinho, J. C. (2013). The role of relational social capital in examining exporter-intermediary relationships. European Business Review, 25(6), 553-570.

Pothukuchi, V., Damanpour, F., Choi, J., Chen, C. C., \& Park, S. H. (2002). National and organizational culture differences and international joint venture performance. Journal of International Business Studies, 33(2), 243-265.

Prahinski, C., \& Benton, W. (2004). Supplier evaluations: Communication strategies to improve supplier performance. Journal of Operations Management, 22(1), 39-62. 
Preacher, K. J., \& Hayes, A. F. (2008). Asymptotic and resampling strategies for assessing and comparing indirect effects in multiple mediator models. Behavior Research Methods, 40(3), 879-891.

Prime, N., Obadia, C., \& Vida, I. (2009). Psychic distance in exporter-importer relationships: A grounded theory approach. International Business Review, 18(2), 184-198.

Racela, O. C., Chaikittisilpa, C., \& Thoumrungroje, A. (2007). Market orientation, international business relationships and perceived export. International Marketing Review, 24(2), 144163.

Ring, P. S., \& Ven, A. H. (1992). Structuring cooperative relationships between organizations. Strategic Management Journal, 13(7), 483-498.

Root, F. R. (1998). Entry Strategies For International Markets. San Francisco, CA: Jossey Bass.

Ruyter, K. d., Moorman, L., \& Lemmink, J. (2001). Antecedents of commitment and trust in customer-supplier relationships in high technology markets. Industrial Marketing Management, 30(3), 271-286.

Saleh, M. A., \& Ali, M. Y. (2009). Determinants of importer commitment in international exchange: An agenda for future research. Journal of Management and Organization, 15(2), 186-205.

Saleh, M. A., Ali, M. Y., \& Julian, C. C. (2014a). International buyer behaviour-commitment relationship: An investigation of the empirical link in importing. International Business Review, 23(2), 329-342.

Saleh, M. A., Ali, M. Y., \& Mavondo, F. T. (2014b). Drivers of importer trust and commitment: Evidence from a developing country. Journal of Business Research, 67(2014), 25232530.

Saleh, A. S., \& Ndubisi, N. O. (2006). An evalution of SME development in Malaysia. International Review of Business Research Papers, 2(1), 1-14

Sarkar, M., Echambadi, R., Cavusgil, S. T., \& Aulakh, P. S. (2001). The influence of complementarity, compatibility, and relationship capital on alliance performance. Journal of the Academy of Marketing Science, 29(4), 358-373.

Schweiger, D. M., \& Goulet, P. K. (2005). Facilitating acquisition integration through deep-level cultural learning interventions: A longitudinal field experiment. Organization Studies, 26(10), 1477-1499.

Shoham, A. (1996). Marketing-mix standardization: Determinants of export performance. Journal of Global Marketing, 10(2), 53-73.

SME Corporation (2015, October 20). SME Annual Report 2015/2016: SME development in Malaysia. Retrieved from SME Corporation: http://www.smecorp.gov.my

Spekman, R. E., Kamauff, J. W., \& Myhr, J. N. (1998). An empirical investigation into supply chain management: A perspective on partnerships. Supply Chain Management: An International Journal, 3(2), 53 - 67.

Sullivan, J., \& Peterson, R. B. (1982). Factors associated with trust in Japanese-American joint ventures. Management International Review, 22(2), 30-40.

Tellefsen, T., \& Thomas, G. P. (2005). The antecedents and consequences of organizational and personal commitment in business service relationships. Industrial Marketing Management, 34(1), 23-37.

Trifunovic, S., Legendre, f., \& Anastasiades, C. (2010). Social trust in opportunistic networks. In 2010 INFOCOM IEEE Conference on Computer Communications Workshops, (pp. 1-6). IEEE. 
Turnbull, P., Oliver, N., \& Wilkinson, B. (1992). Buyer-supplier relations in the UK - automotive industry: Strategic implications of the Japanese manufacturing model. Strategic Management Journal, 13(2), 159-168.

Vereecke, A., \& Muylle, S. (2006). Performance improvement through supply chain collaboration in Europe. International Journal of Operations \& Production Management, 26(11), 11761198.

Villena, V. H., Revilla, E., \& Choi, T. Y. (2011). The dark side of buyer-supplier relationships: A social capital perspective. Journal of Operations Management, 29(6), 561-576.

Weber, E. U., \& Hsee, C. (1998). Cross-cultural differences in risk perception, but cross-cultural similarities in attitudes towards perceived risk. Management Science, 44(9), 1205-1217.

Yli-Renko, H., Autio, E., \& Sapienza, H. J. (2001). Social capital, knowledge acquisition, and knowledge exploitation in young technology-based firms. Strategic Management Journal, 22(6/7), 587-613.

Zaheer, A., \& Kamal, D. F. (2011). Creating trust in piranha-infested waters: The influence of buyer, supplier and host country contexts. Journal of International Business Studies, 42(1), 48-55.

Zou, S., Taylor, C. R., \& Osland, G. E. (1998). The EXPERF scale: A cross national generalized export performance measure. Journal of International Marketing, 6(3), 37-58. 